\title{
An explorative study on Biomedical Waste Management in a Psychiatric Hospital of India
}

\author{
J.Hazarika, A C Sarmah*, M.Das**. \\ Department of Microbiology, ${ }^{*}$ Department of Pathology, \\ ** Department of Biochemistry, LGB Regional Institute of Mental Health, Tezpur, Assam.
}

\begin{abstract}
Background: In accordance with Bio-Medical Waste(management and handling)Rules, 1998, it is the duty of every "occupier" i.e. a person who has the control over the institution and or its premises, to take all steps to ensure that waste generated is handled without any adverse effect to human health and environment. To improve hospital waste management, it is important to begin by surveying the facility of current hospital waste practices. A waste survey should therefore be undertaken about the information of the waste planning process.

Methods: A waste survey was undertaken about the information of the waste planning process; as to improve hospital waste management, it is important to begin by surveying the facility of current hospital waste practices. This survey should provide information on types and quantity of wastes, which are arising at each point of production, and methods of storage, handling, treatment and disposal.

Results: In our survey it is seen that, management, handling and treatment of Biomedical Waste are done as per Bio-Medical Waste Rules, 1998.

Conclusion: After analyzing the study it was felt that the healthcare waste management should go beyond data compilation, enforcement of regulations and acquisition of better equipment. It should be supported through appropriate education, training and the commitment of the healthcare staff, management and healthcare managers within an effective policy and legislative framework.
\end{abstract}

Key words: Biomedical waste management (BMW), Psychiatric Hospital

\section{INTRODUCTION:}

The waste produced in the course of health care activities caries a higher potential for infection and injury than any other type of waste ${ }^{1}$. The proper BioMedical Waste Management in the hospital is not only the statuary (legal) obligation because of the BioMedical Waste (Management and Handling) Rules ${ }^{2}$

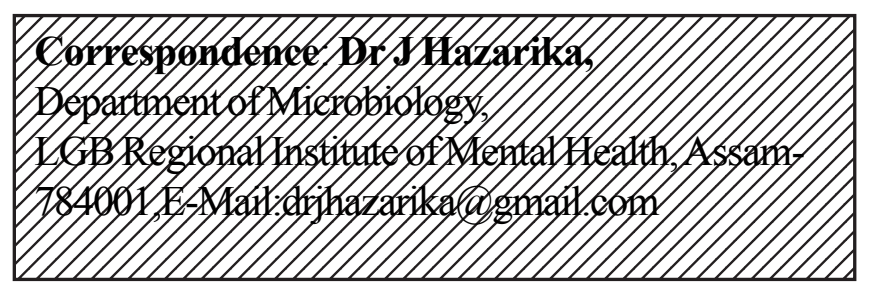

of 1998 but also associated with many health and environment hazards, if not managed properly. However, very few health institutions are implementing them properly because of lack of awareness and difficulties at the institutional as well as operational level such as lack of resources, including personnel, space and equipment, lack of technical knowledge for scientific waste disposal. In addition, waste disposal is monitored by Pollution Control Board and Environmental Ministry, which has no linkage with the Health Department ${ }^{3}$. Bio-Medical Waste means "any solid, fluid or liquid waste, including its container and 
any intermediate product, which is generated during its diagnosis, treatment or immunization of human beings or animals, in research pertaining thereto, or in the production or testing of biological and the animal waste from slaughter houses or any other like establishments". Hospital waste refers to all waste, biologic or non biologic that is discarded and not intended for further use. Medical waste is a subset of hospital waste; it refers to the material generated as a result of diagnosis, treatment or immunization of patients and associated biomedical research ${ }^{4}$.Biomedical waste(BMW) is generated in hospitals, research institutions, health care teaching institutes, clinics, laboratories, blood banks, animal houses and veterinary institutes ${ }^{5}$.According to WHO report, $85 \%$ of hospital waste is non hazardous waste $^{6}$. The average quantity of hospital solid waste produced in India ranges from 1.5 to $2.2 \mathrm{~kg} /$ day $/ \mathrm{bed}^{7}$. Handling, segregation, mutilation, disinfection, storage, transportation and final disposal are vital steps for safe and scientific management of BMW in any establishment $^{8}$.It is a collective initiative and shared responsibility of all viz. doctors, nurses, paramedical staff, cleaning staff, all employees and administrators. All personnel should be made aware and trained regarding biomedical waste. To improve hospital waste management, it is important to begin by surveying the facility of current hospital waste practices. A waste survey is therefore being undertaken about the information of the waste planning process. The purpose of the study is to review the current status of Waste Management in the Hospital on types and quantity of wastes, which are arising at each point of production and methods of storage, handling, treatment and disposal; and provide recommendation to aide in achieving the optimal Hospital Waste Management.

\section{MATERIALS AND METHOD}

Present study was carried out in a Psychiatric Hospital in the year of 2009.Methods of storage and segregation at ward/department level, internal transportation, kerb site storage, external transportation and on site final disposal/offsite disposal were studied by direct observation and infrastructure for the same were studied. Types of waste generated and quantity of waste are estimated by discussion, interviews and by physical checks. The average values are presented in the prescribed from. The study was carried out as a plan of development; leading to comprehensive, safe and eco-friendly management \& disposal. Each step or part of the study led to another step in seriatim ultimately culminating in a comprehensive system of waste management.

\section{RESULTS}

The practical operational aspects regarding management of Bio-Medical Wastes at a Psychiatric Hospital has been described under each step starting with the generation and ending with final disposal of wastes. Since the studies were done in a Psychiatric Hospital, so the waste generated in the Hospital is very less in compared to other type of Hospitals. Pathology, Microbiology and Biochemistry departments generate sizable amount of biomedical waste. Studies carried out have indicated that about $1.1 \mathrm{~kg}$ of solid wastes generated per day which gives an idea about the volume of waste generated on day to day basis. Hospital Waste management committee looks after the overall activity of Bio-medical waste management process.

(A)Generation of Waste: About $85 \%$ of hospital wastes are non-hazardous, whereas $10 \%$ are infectious and $5 \%$ are non-infectious but they are included in hazardous wastes. Non-hazardous wastes generated from office, kitchen, Pantries in wards etc. And hazardous wastes generated from Laboratories, Wards, Treatment Room, Nursing station etc.

(B)Segregation of Waste: Segregation or the separation of different types(categories) of waste by sorting at the point of segregation has been considered as the "key" for the entire process as it allows special attention to be given to the relatively small quantities of infections and hazardous waste, thus reducing the risks and cost of waste management. Conversely small errors at this stage can create lot of subsequent 
problems. Category No.1 (Human anatomical waste) in this study. Segregation of waste is done properly as and Category No.2 (animal waste) waste are not found per BMW rules 1998 as mentioned in schedule I (Table 1).

Table 1(Schedule I)

\section{CATEGORIES OF BIO-MEDICAL WASTE}

\begin{tabular}{|c|c|c|}
\hline Option & Waste Category & Treatment \& Disposal \\
\hline $\begin{array}{l}\text { Category } \\
\text { No. I }\end{array}$ & $\begin{array}{l}\text { Human Anatomical Waste } \\
\text { (human tissues, organs, body parts) }\end{array}$ & $\begin{array}{l}\text { Incineration@/deep } \\
\text { burial* }\end{array}$ \\
\hline $\begin{array}{l}\text { Category } \\
\text { No. } 2\end{array}$ & $\begin{array}{l}\text { Animal Waste } \\
\text { (animal tissues, organs, body parts carcasses, } \\
\text { bleeding parts, fluid, blood and experimental animals } \\
\text { used in research, waste generated } \\
\text { by veterinary hospitals colleges, discharge from } \\
\text { hospitals, animal) }\end{array}$ & $\begin{array}{l}\text { Incineration @ / deep } \\
\text { burial* }\end{array}$ \\
\hline $\begin{array}{l}\text { Category } \\
\text { No } 3\end{array}$ & $\begin{array}{l}\text { Microbiology \& Biotechnology Waste } \\
\text { (wastes from laboratory cultures, stocks or specimens } \\
\text { of micro-organisms live or attenuated vaccines, } \\
\text { human and animal cell culture used in research and } \\
\text { infectious agents from research and industrial } \\
\text { laboratories, wastes from production of biologicals, } \\
\text { toxins, dishes and devices used for transfer of } \\
\text { cultures) }\end{array}$ & $\begin{array}{l}\text { local autoclaving / micro- } \\
\text { waving / incineration@ }\end{array}$ \\
\hline $\begin{array}{l}\text { Category } \\
\text { No } 4\end{array}$ & $\begin{array}{l}\text { Waste sharps } \\
\text { (needles, syringes, scalpels, blades, glass, etc. that } \\
\text { may cause puncture and cuts. This includes both used } \\
\text { and unused sharps) }\end{array}$ & $\begin{array}{l}\text { disinfection (chemical } \\
\text { treatment@o1/auto } \\
\text { claving/micro- waving } \\
\text { and mutilation/ } \\
\text { shredding" }\end{array}$ \\
\hline $\begin{array}{l}\text { Category } \\
\text { No } 5\end{array}$ & $\begin{array}{l}\text { Discarded Medicines and Cytotoxic drugs } \\
\text { (wastes comprising of outdated, contaminated and } \\
\text { discarded medicines) }\end{array}$ & $\begin{array}{l}\text { Incineration@/destruct } \\
\text { ion and drugs disposal in } \\
\text { secured landfills drugs } \\
\text { disposal in secured }\end{array}$ \\
\hline $\begin{array}{l}\text { Category } \\
\text { No } 6\end{array}$ & $\begin{array}{l}\text { Solid Waste } \\
\text { (Items contaminated with blood, and body fluids } \\
\text { including cotton dressings, soiled plaster casts, lines, } \\
\text { beddings, other material } \\
\text { contaminated with blood) }\end{array}$ & $\begin{array}{l}\text { Incineration@ } \\
\text { autoclaving / micro- } \\
\text { waving }\end{array}$ \\
\hline $\begin{array}{l}\text { Category } \\
\text { No. } 7\end{array}$ & $\begin{array}{l}\text { Solid Waste } \\
\text { (wastes generated from disposable items other than } \\
\text { the waste shaprs such as tubings, catheters, } \\
\text { intravenous sets etc). }\end{array}$ & $\begin{array}{l}\text { disinfection by chemical } \\
\text { treatment @ } \\
\text { autoclaving/micro- } \\
\text { waving and mutilation/ }\end{array}$ \\
\hline
\end{tabular}

a) Chemicals treatment using at least 1\% hypochlorite solution or any other equivalent chemical reagent. It must be ensured that chemical treatment ensures disinfection.

\#\# Multilation/shredding must be such so as to prevent unauthorised reuse.

(a) There will be no chemical pretreatment before incineration. Chlorinated plastics shall not be incinerated.
- Deep burial shall be an option available only in towns with population less than five lakhs and in rural areas.

+ Options given above are based on available technologies. Occupier/operator wishing to use other State-of-the-art technologies shall approach the Central Pollution Control Board to get the standards laid down to enable the prescribed authority to consider grant of authorization. (Schedule I; adapted from BioMedical Waste (Management and Handling) Rules, 1998) 
(C)Collection of Waste: Collection of Bio-medical Wastes is done as per biomedical waste (Management and handling) rules in colour coded plastic bags/container. The container for collection is strategically located at all points of waste generated site like Indoor Patient Department, Outdoor Patient Department,
Laboratories, Pharmacy and Nursing Station. The process of collection is documented in a register, the coloured polythene bags are replaced and the garbage bin is cleaned with disinfectant regularly. The quantum of waste produced in a period of one year in different sections of the Hospital is detailed in Table: 2 .

Table 2:Category-wise quantity of waste treated along with treatment facility in the year 2009.

\begin{tabular}{|c|c|c|c|}
\hline Colour Coding & 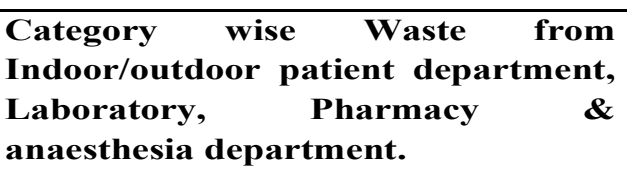 & $\begin{array}{l}\text { Quantity of } \\
\text { waste treated } \\
\text { Yearly basis }\end{array}$ & Treatment facility \\
\hline \multirow[b]{2}{*}{ Yellow } & Cat. 1, Cat. 2, & Nil & \multirow{2}{*}{ Incineration } \\
\hline & $\begin{array}{l}\text { Cat. } 3, \\
\text { Cat. } 6\end{array}$ & $48.4 \mathrm{~kg} /$ Year & \\
\hline Red & Cat. 3, Cat. 6, Cat.7. & $\begin{array}{l}245.7 \mathrm{~kg} / \\
\text { Year }\end{array}$ & $\begin{array}{l}\text { Chemical } \\
\text { Treatment }\end{array}$ \\
\hline $\begin{array}{l}\text { Blue/White } \\
\text { translucent }\end{array}$ & Cat. 4, Cat. 7. & $98.6 \mathrm{~kg} /$ Year & $\begin{array}{l}\text { Chemical Treatment } \\
\text { and } \\
\text { destruction/shredding }\end{array}$ \\
\hline Black & $\begin{array}{l}\text { Cat. } 5 \\
\text { Cat. } 9 \\
\text { Cat. } 10 . \text { (solid) }\end{array}$ & $\begin{array}{l}5 \mathrm{~kg} / \text { Year } \\
0.6 \mathrm{~kg} / \text { Year }\end{array}$ & $\begin{array}{l}\text { Disposal in secured } \\
\text { landfill }\end{array}$ \\
\hline-- & $\begin{array}{l}\text { Cat. } 8 \text {, Liquid waste } \\
\text { Cat. } 10 \text {, Liquid waste }\end{array}$ & $\begin{array}{l}38520 \text { liters/ } \\
\text { Year }\end{array}$ & $\begin{array}{l}\text { chemical treatment } \\
\text { and discharge into } \\
\text { drains }\end{array}$ \\
\hline
\end{tabular}

(D)Storage and transport of Waste: Wastes are kept at the site of generation and transit to the point of treatment and final disposal. Usually wastes are finally disposed within 12-24 hours in the Hospital. The transport is done though covered trolleys from different area of waste collected site and deposited in area near the incinerator site. Personal protective equipment and accessories are provided to the workers according to the requirement. The general waste is deposited at the municipal dumps which are transported in the vehicle by Municipality authorities. (E)Treatment and Disposal of Hospital Waste: Most of the waste (about $80 \%-90 \%$ ) generated in this Psychiatric Hospital are general waste which is similar to the waste generated in house and offices. These waste is non toxic and non infectious, and comprise of paper, leftover food, peels of fruits, disposable and paper container, card board boxes, outer cover or wrapping of disposable items like syringes etc. These general wastes are put into green coloured polythene bags are deposited at the municipal dump. It is subsequently collected by the local municipal authorities for disposal in every day. The waste collected in yellow coloured bags is transported to the site of incineration. The incinerator is maintained by the Engineering services department and is manned by supervisor and workers. The ash produced by incineration is sent for secured land filling. Regular monitoring of the process is carried out by the engineers as per Pollution Control Board norms and feedback provide to officer in charge. The waste collected in blue bags is transported to the site of 
autoclaving and shredding for treatment. Autoclaving and Chemical treatment are done for Category3, Category 6 and Category 7 waste. Secured sanitary landfill is considered for medical for medical wastes which do not require incineration or disinfection. Category 5, Category 9 and Category 10(solid) wastes are disposed in secured landfill. Liquid and chemical wastes are disinfected and then discharged into drains/ sewers where it is taken care of by the principle of dilution and dispersal. Needles and syringes are destroyed with the help of needle destroyer and syringe cutters at the point of generation. Sharps are kept in puncture resistant containers to avoid injuries and infection to those handling them. After disinfection and mutilation of sharps they are disposed in secured landfills.

\section{DISCUSSION}

The current waste management practice has been observed in one of the Psychiatry Hospital of India. After analyzing the study it is felt that the healthcare waste management should go beyond data compilation, enforcement of regulations and acquisition of better equipment. It should be supported through appropriate education, training and the commitment of the healthcare staff, management and healthcare managers within an effective policy and legislative framework. Hospital having defunct/ defective incinerators should be made to utilize central incineration facility; as efforts of Govt. are towards reducing the number of incinerators in cities to prevent rise in air pollution. Since the cost of setting waste management facility is too high, the only way is to have a common disposal facility. There are many private waste management facilities being set up now in most cities and entered into an agreement with the private company. Incinerators, which do not confirm to the design and emission norms as per rules, must be modified and air pollution control system may be retrofitted to minimize the emission level. No incinerator shall be allowed to operate unless equipped with Air Pollution Control Device(APCD).Installation of individual incineration facility by a healthcare unit shall be discouraged as far as possible but approval may be granted only in certain inevitable situations where no other option available. The liquid waste management needs more attention and effluent treatment facilities need to be viewed seriously. General awareness among the hospital staff regarding Bio-medical waste is lacking. Regular training and workshops should therefore be conducted. Recycling of disinfected waste needs to be emphasized. Hospital Waste Management committee formulate the details plan of action in regard to segregation, collection, storage and transport of waste from all patient care areas as well as other activity in relation to Hospital Waste. A policy need to be formulated based on reduce, recover, reuse and dispose.

In conclusion, to improve the waste management system, the medical staff should be more involved in waste management system and importance of this subject should be emphasized on everyone including public, patients and hospital staff. Media can also generate awareness amongst the citizens about various types of waste and their safe disposal and treatment.

\section{REFERENCES}

1. Park K.Hospital Waste Mangement.Park's Textbook of Preventive and Social Medicine.M/s Banarasdias Bhanot Publication, Jabalpur.20 th Edition, 2009:694-699.

2. Bio-medical Waste (Management and Handling) Rules, 1998.Ministry of Environment and Forests Notification,New Delhi.

3. Bio-medical waste management at Community Health Centre August 12, 2007.Available at http;//cbhihsprod.nic.in/ searnum.asp?PNum=164.

4. Rutala WA,Weber DJ.Disinfection,Sterlization and control of hospital Waste.In:Mandell,Douglas and Bennett's Principle and Practice of Infectious diseases.Elsevier Churchill Livingstone Publication. $6^{\text {th }}$ Edition, 2005;3371-47.

5. Sharma M: Hosital waste management and its monitoring. Jaypee brothers Medical Publication. $1^{\text {st }}$ Edition, 2002.

6. Pruss A,Cirouit E and Rushbrook P.Safe management of waste from healthcare activities, WHO;1999.

10. Kumar M:Hospital Waste Disposal,a planning consideration, National seminar on hospital architecture,planning and enginerring, 1995;IV:40-450.

11. Acharya DB,Sing Meeta.The book of Hospital Waste Mnagement.Minerva Press,New Delhi2000;15,47. 